\title{
TERAPI MEWARNAI SOLUSI UNTUK MENGURANGI STRES AKADEMIK MAHASISWA TERHADAP KULIAH ONLINE Anna Aisa ${ }^{*}$
}

${ }^{1}$ Bimbingan dan Konseling Pendidikan Islam, Institut Agama Islam Negeri Madura, Jalan Panglegur KM 04, Pamekasan, Timur, 69371, Indonesia

*e-mail: annaaisa@iainmadura.co.id.

\begin{tabular}{ll}
\hline \hline & Abstract \\
\hline Keywords: & One of the Indonesian government's policies to break the chain of transmission of the \\
Academic Stress; & COVID-19 virus is physical distancing. The government restricts activities that are \\
Online Lectures. & not too important. All activities are temporarily carried out at home, including \\
lectures. Lecture activities that were originally face-to-face must switch to online \\
lectures. This changing pattern of lecture approach triggers the emergence of \\
academic stress in students. High academic stress can lead to impaired thought \\
processes, perceptions and problem-solving abilities as well as sleep disorders and \\
reduced decision-making power. If left unchecked, it will interfere with the quality \\
of life of students. Therefore, other activities are needed to fill free time and reduce \\
students' academic stress. One of them is art therapy with the coloring method. This \\
activity is considered to be able to reduce the level of academic stress. The method \\
used is descriptive. Data were collected through interviews with the subjects and \\
analyzed by the data explication method. The subjects were five people who were \\
obtained by purposive method. The results showed that the five subjects experienced \\
a decrease in academic stress levels after carrying out coloring therapy activities. It \\
can be seen in the enthusiasm and efforts of the five subjects to return to active \\
participation in online lectures, the enthusiasm to do the assignments given by the \\
lecturers and the enthusiasm to ask questions and find out independently about \\
information about learning materials and information that has not been understood.
\end{tabular}

\begin{tabular}{ll}
\hline \hline & Abstrak: \\
\hline Kata Kunci: & Salah satu kebijakan pemerintah Indonesia untuk memutus mata rantai penularan \\
Terapi Mewarnai; & virus covid 19 adalah pembatasan sosial atau lebih dikenal dengan psysical \\
Stres Akademik; & distancing. Pemerintah membatasi kegiatan-kegiatan yang tidak terlalu penting. \\
Kuliah Online. & Semua kegiatan sementara waktu dilakukan di rumah, termasuk perkuliahan. \\
& Kegiatan perkuliahan yang semula secara tatap muka harus beralih menjadi kuliah \\
& online. Pola perubahan pendekatan perkuliahan ini memicu munculnya stres \\
& akademik pada mahasiswa. stres akademik yang tinggi dapat menyebabkan \\
& gangguan proses berpikir, persepsi dan kemampuan memecahkan masalah serta \\
& gangguan tidur dan berkurangnya kekuatan pengambilan keputusan. Jika dibiarkan, \\
& akan mengganggu kualitas hidup mahasiswa. Oleh karena itu, diperlukan adanya \\
& kegiatan lain untuk mengisi waktu luang dan mengurangi stres akademik \\
& mahasiswa. Salah satunya dengan terapi seni dengan metode mewarnai. Kegiatan ini \\
& dinilai mampu menurunkan tingkat stres akademik. Metode yang digunakan adalah \\
& deskriptif. Data dikumpulkan melalui wawancara terhadap subjek dan dianalisis \\
& dengan metode eksplikasi data. Subjek berjumlah lima orang yang diperoleh dengan \\
& dengan cara purposif. Hasil penelitian menunjukkan bahwa kelima subjek \\
& mengalami penurunan tingkat stres akademik setelah melaksanakan aktivitas terapi \\
& mewarnai. Tampak pada semangat dan usaha kelima subjek untuk kembali aktif \\
mengikuti perkuliahan online, semangat mengerjakan tugas yang diberikan dosen \\
dan semangat untuk bertanya serta mencari tahu secara mandiri mengenai informasi \\
\hline
\end{tabular}




\section{PENDAHULUAN}

Virus corona sudah menyebar di seluruh dunia lebih dari 1 tahun. Pemerintah Indonesia telah menetapkan beberapa kebijakan untuk memutus mata rantai penularan virus covid 19 salah satunya yaitu pembatasan sosial atau lebih dikenal dengan psysical distancing. Pemerintah mengharuskan masyarakat untuk berada di dalam rumah dan membatasi kegiatan-kegiatan yang tidak terlalu penting. Semua kegiatan yang biasa dilakukan di luar rumah seperti bekerja, belajar, kuliah, dan lain sebagainya sementara waktu dilakukan di rumah.

Dalam dunia pendidikan di Indonesia, Hampir seluruh universitas baik negeri maupun swasta memberlakukan sistem perkuliahan online. Kemendikbud mengeluarkan surat edaran instruksi kepada seluruh universitas di Indonesia untuk melakukan perkuliahan jarak jauh (daring) secara online. Kuliah daring atau yang biasa disebut dengan kuliah online adalah proses belajar mengajar berbasis internet yang dilakukan oleh mahasiswa, maupun dosen, dimana peserta dapat mengakses materi, saling berinteraksi, mendiskusikan materi, dan mengembangkan diri lewat pengalaman belajar berbasis online (Universitas Indonesia,2020).

Kegiatan perkuliahan yang semula secara tatap muka harus beralih menjadi kuliah online. Pola perubahan pendekatan perkuliahan ini tidak jarang menjadi suatu masalah tersendiri. Masalah-masalah tersebut diantaranya internet melambat dan mahasiswa kurang memahami materi (Panchanov, 2020), tidak adanya kuota bagi mahasiswa yang kurang mampu (Gunadha \& Rahmayunita, 2020), kesiapan dosen menyiapkan materi daring, dan kesiapan mahasiswa menyiapkan kuota internet (Satria, 2020), hingga tragedi meninggalnya mahasiswa di Sulawesi Selatan akibat mencari sinyal untuk mengerjakan tugas daring (Amiruddin, 2020; Mappi, 2020). Selang hampir satu tahun lebih berjalan, Perkulihan online menimbulkan beberapa masalah. Banyak mahasiswa mengeluh karena kuliah berbasis online membuat mereka kurang paham akan materi yang dijelaskan oleh dosen, pemberian materi lewat PPT maupun video dianggap kurang maksimal ditambah lagi kapasitas ruang dan media untuk mengungkapkan pendapat dan pertanyaan masih terbatas. Masalah-masalah tersebut akan memicu munculnya stres akademik pada mahasiswa.

Stres akademik merupakan respon fisik atau psikis karena ketidakmampuan dalam mengubah tingkah laku atau penampilan dengan serangkaian kegiatan seperti: menulis, 
membaca, mengamati, mendengarkan, meniru, sebagai akibat dari tekanan-tekanan atau ketidaksesuaian antara tuntutan yang diterima dengan kemampuan yang dimiliki (Aryani, 2016). Jika dikaitkan dengan masalah-masalah yang timbul sepanjang pelaksanaan kuliah online, maka stres akademik pada mahasiswa dapat dimanifestasikan melalui respon fisik atau psikis akibat kurang mampu memahami materi perkuliahan yang diberikan secara online, kurang mampu menyelesaikan tekanan tugas maupun tuntutan kuota yang senantiasa harus terpenuhi saat kuliah, serta tuntutan demografi wilayah tempat tinggal yang menunjang stabilnya koneksi internet itu sendiri. Penelitian telah menunjukkan bahwa tingkat stres akademik yang tinggi dapat menyebabkan gangguan proses berpikir, persepsi dan kemampuan memecahkan masalah serta gangguan tidur dan berkurangnya kekuatan pengambilan keputusan (Shadi, Peyman, Taghipour, \& Tehrani, 2018).

Respon stres pada setiap orang akan berbeda-beda. Respon stres dapat berupa perilaku menghindari tugas, menarik diri, sulit tidur, tidur terus, dan sulit makan. Secara fisiologis respon stres dapat berupa jantung berdebar, tekanan darah tinggi, panas, keringat dingin, pusing, sakit perut, cepat lelah. Sedangkan pada aspek psikologis, stres dapat berbentuk frustasi, depresi, kecewa, merasa bersalah, bingung, takut, tidak berdaya, cemas, tidak termotivasi, dan gelisah (Wahyuni,2017). Berdasarkan hasil wawancara dengan beberapa mahasiswa IAIN Madura, mahasiswa MB kurang memahami materi yang disampaikan dosen melalui PPT maupun voice note, secara fisiologis repon yang ditunjukkan adalah berkeringat dingin, sakit perut dan ingin buang air besar. Sedangkan respon psikologis yang dirasakan adalah merasa bingung dengan materi yang disampaikan, merasa takut dimahari dosen dan takut mendapat nilai jelek saat ujian. Begitu juga dengan mahasiswa HL saat perkuliahan online, dia merasa sering sekali sulit tidur karena memikirkan tugas yang belum dipahami, ia juga merasa pusing dan cepat lelah setiap kali mengingat tugas yang belum dipahaminya.

Dari kasus-kasus tersebut sudah Nampak bahwa stres akademik yang dihadapi mahasiswa akibat perkuliahan online cukup meresahakan dan harus segera mendapatkan penanganan. Kuliah online yang sudah menjadi rutinitas harian bagi mahasiswa menjadi momok yang menakutkan ditambah lagi dengan tuntutan yang tinggi bagi penerima beasiswa yang harus tetap mempertahankan prestasi akademik tiap tahunnya. Jika dibiarkan, ini akan mengganggu kualitas hidup mahasiswa. Oleh karena itu, diperlukan adanya kegiatan lain untuk mengisi waktu luang dan mengurangi stres akademik mahasiswa. Salah satunya dengan terapi seni dengan metode mewarnai. Kegiatan ini dinilai mampu menurunkan tingkat stres. Apalagi saat ini banyak beredar buku mewarnai yang diperuntukkan untuk orang dewasa. 
Malchiodi (2013) menyatakan bahwa terapi seni adalah suatu bentuk terapi yang bersifat ekspresif dengan menggunakan materi seni, seperti lukisan, kapur, spidol dan atribut seni lainnya. Menurut Ganim (dalam Heksan, 2010), menyatakan bahwa seni memiliki manfaat sebagai terapi penyembuhan. Hal ini disebabkan karena (a) seni dapat merupakan ekspresi langsung dari mimpi atau fantasi ke dalam bentuk visual; (b) seni memproyeksikan alam ketidaksadaran; (c) seni memberikan perasaan senang atau nyaman; (d) seni bersifat fleksibel, tidak ada yang benar ataupun salah; (e) seni tidak memiliki batasan usia; dan (f) seni membantu mengungkapkan perasaan bagi orang yang sukar mengungkapkan perasaannya secara verbal. Adapun terapi seni yang akan peneliti gunakan adalah terapi seni mewarnai.

Terapi seni dengan metode mewarnai dipilih karena ketika seseorang sedang mewarnai, secara otomatis ia akan mengalihkan fokus atau konsentrasi dari sumber stres. Emosi yang dirasakan bisa dirilis atau dicurahkan lewat goresan warna di atas kertas, kanvas, atau apapun medianya. Saat berhasil menuangkan emosinya, maka intensitas negatif yang dirasakan akan perlahan menurun. Segala kecemasan, ketakutan, kesedihan akan pelan-pelan berkurang sehingga diri bisa lebih rileks. Saat hal ini terjadi, tingkat stres juga akan ikut menurun. Saat seseorang dibebaskan untuk memilih warna yang disuka, tidak ada patokan yang mengikat. justru yang dirasakan dapat lepas sepenuhnya jika memilih secara bebas. Terapi Seni menggabungkan proses pembuatan seni (gambar, lukisan, patung, dan media seni lainnya) dengan metode psikoterapi untuk meningkatkan dan memperbaiki kesejahteraan psikologis individu dari segala usia (Fatmawati, 2015). Terapi Seni juga dapat dijadikan sarana untuk membantu individu dari segala usia dalam menciptakan insight dan penyembuhan terhadap permasalahan emosional atau trauma, menyelesaikan konflik dan masalah dalam kehidupan sehari-hari, dan meningkatkan pencapaian kesejahteraan (Malchiodi, 2013).

Tujuan penelitian ini adalah (1) untuk mengetahui gambaran stres akademik yang dialami oleh mahasiswa IAIN Madura, (2) untuk mengetahui apakah terapi mewarnai dapat menurunkan stres akademik mahasiswa. (3) untuk mengetahui bagaimana perasan dan perubahan tingkat stres akademik mahasiswa setelah mendapatkan terapi mewarnai.

\section{METODE}

Penelitian ini mengunakan metode penelitian kualitatif dengan pendekatan deskriptif. Fokus penelitian ini adalah untuk mengetahui manfaat terapi mewarnai dalam membantu 
menurunkan stres akademik mahasiswa. Peneliti akan menggali bagaimana proses terapi mewarnai dan dampaknya pada mahasiswa yang mengalami stres akademik serta faktorfaktor yang mempengaruhi menurunnya stres akademik mahasiswa. Penelitian ini menggunakan teknik purposive dengan karakteristik subjek dalam penelitian ini adalah mahasiswa aktif IAIN Madura perwakilan dari semua fakultas yang mengalami stres akademik. Metode pengumpulan data yang digunakan adalah wawancara, observasi, dan catatan lapangan.

Analisis data pada penelitian ini mengacu pada teknik eksplikasi. Tahap analisis pertama, peneliti melakukan transkripsi hasil rekaman wawancara yang selanjutnya dibaca

berulang beberapa kali agar dapat memahami fenomena secara utuh. Selanjutnya, peneliti mulai membuang pernyataan berulang serta memilah unit makna yang relevan dengan penelitian untuk dimasukkan ke dalam tabel DFI. Tahap ketiga peneliti memahami urutan umum dari sejumlah deskripsi di dalam tabel DFI guna mengidentifikasikan episode-episode yang muncul. Selanjutnya, pada masing-masing episode disusunlah tema yang mengacu pada gagasan dasar, yakni makna yang diungkapkan oleh subjek. Pada tahap terakhir, peneliti meringkas dan memadukan seluruh tema-tema yang muncul pada setiap subjek. Peneliti memberikan penjelasan mengenai tema yang muncul dan memberikan kutipan dari pernyataan subjek yang telah diberikan penomoran.

\section{HASIL}

Sebjek pertama (MB) adalah mahasiswa program studi Bimbingan dan Konseling Pendidikan Islam (BKPI) Fakultas Tarbiyah, IAIN Madura. Subjek kedua (HL) adalah mahasiswa program studi Pendidikan Agama Islam (PAI) Fakultas Tarbiyah, IAIN Madura. Subjek ketiga (RE) adalah mahasiswa program studi Hukum Ekonomi Syari'ah (HES) Fakultas Syari'ah, IAIN Madura. Subjek keempat (SA) adalah mahasiswa program studi Perbankan Syari'ah (PS) Fakultas Ekonomi dan Bisinis Islam, IAIN Madura. Subjek kelima (AE) adalah mahasiswa program studi Komunikasi dan Penyiaran Islam (KPI) Fakultas Ushuluddin dan Dakwah, IAIN Madura.

Berdasarkan teknik eksplikasi data, peneliti membagi pengalaman kelima subjek ke dalam empat tahap, yaitu: (a) kondisi stres akademik yang dialami, (b) pandangan dan pendapat subjek tentang terapi mewarnai, (c) pengalaman saat mendapatkan terapi mewarnai, dan (d) pengalaman dan perasaan setelah mendapatkan terapi mewarnai. Tahap pertama mengungkapkan kondisi stres akademik yang subjek alami, gejala-gejala yang timbul baik 
gejala fisiologis maupun gejala psikologis serta bagaimana dampaknya bagi kehidupan keseharian subjek. Tahap kedua yaitu pandangan dan pendapat subjek tentang terapi mewarnai, apakah mereka sudah mengetehui tentang terapi mewarnai sebelumnya, sejak kapan subjek mengetahui dan darimana subjek mendapatkan informasi mengenai terapi mewarnai. Tahap ketiga yaitu pengalaman subjek saat mendapatkan terapi mewarnai, kesulitan apa yang dialami saat memulai mewarnai sebuah gambar, perasaan apa yang dirasakan saat melihat warna-warna yang sudah tertuang dalam buku gambar dan bagimana perasaan subjek ketika berhasil mewarnai sebuah gambar. Tahap terakhir yaitu pengalaman subjek setelah mendapatkan terapi mewarnai, perasaan subjek setelah berhasil mewarnai sebuah gambar dan apakah ada perubahan tingkat stres akademik sebelum dan sesudah mewarnai.

\section{Subjek \#1 (MB)}

Subjek merupakan mahasiswa semester enam program studi Bimbingan dan Konseling Pendidikan Islam (BKPI) Fakultas Tarbiyah, IAIN Madura. Subjek adalah mahasiswa penerima beasiswa bidikmisi sejak tahun pertama menjadi mahasiswa. Sejak pertama kali perkulihan online diterapkan subjek merasa takut dan cemas. Rasa takut yang diarasakan dikarenkan nilai yang didapat harus meningkat dari semester sebelumnya, minimal harus dipertahankan, mengingat subjek adalah penerima beasiswa bidik misi yang harus mempertahankan nilai tiap semesternya. Rasa cemas yang muncul dikarenkan subjek tidak mempunyai handphone (HP) dengan fitur yang canggih, sehingga ketika ada tugas membuat video, subjek merasa kesulitan dan cemas akan tugas yang belum selesai.

Respon fisiologis yang sering terjadi adalah susah tidur dan selalu berkeringat dingin tiap mengingat tugas yang diberikan dosen.

Terapi mewarnai sudah sangat akrab ditelinga subjek, mengingat subjek adalah mahasiswa program studi bimbingan dan konseling yang mepelajari ilmu-ilmu psikologi beserta segala macam tekniknya. Namun, meskipun subjek sudah mengatahui tentang terapi mewarnai, subjek belum pernah menerapkan terapi mewarnai dalam kehidupannya.

Ketika pertama kali menerapkan terapi mewarnai, subjek merasa senang karena mengingatkan ia pada masa-masa menjadi siswa taman kanak-kanak. Saat memegang pensil warna setelah sekian lama tidak dilakukan membuat subjek tidak henti-hentinya tersenyum sambil sesekali teringat masa kecilnya yang menyenagkan bersama teman-teman dan saudara-saudaranya. Perasaan senang dan puas subjek rasakan lagi ketika berhasil mewarnai 
sebuah gambar. Kesulitan yang dialami tidak begitu berat yakni belum bisa mewarnai sesuai dengan batas garis yang ada, warna yang diterpakan masih sedikit-sedikit melewati batas garis yang tersedia.

Setelah menyelesaikan sebuah gambar untuk diwarnai, subjek merasa puas dan lega. Ada rasa bangga pada diri sendiri karena bisa mewarnai gambar dengan baik. Melihat berbagai warna yang ada membuat subjek merasa tenang dan damai. Subjek mengulangi mewarnai selama beberapa kali dengan pola gambar yang berbeda. Perubahan tingkat stres akademik dapat dirasakan langsung oleh subjek. Setelah mewarnai, subjek mempunyai semangat untuk membuka kembali materi-materi yang telah diberikan oleh dosen dan mulai mengerjakan tugas yang diberikan dengan perasaan senang dan tenang.
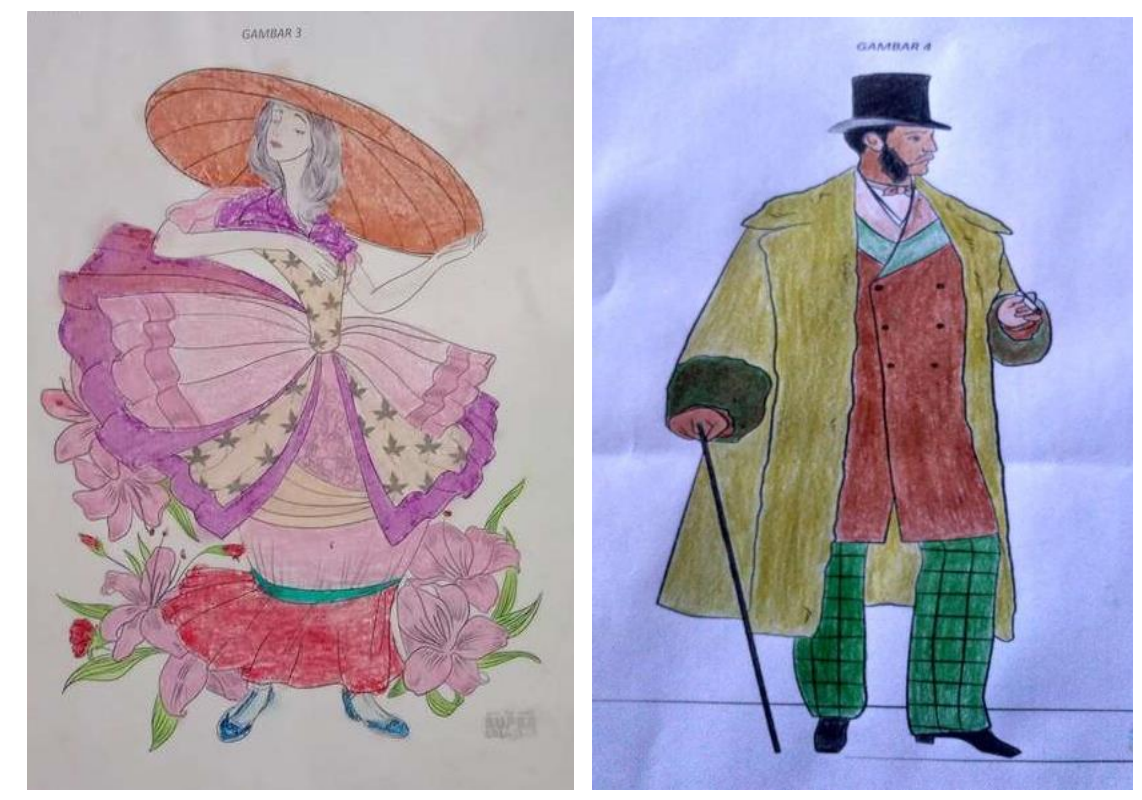

Gambar 1. Hasil mewarnai subjek 1

\section{Subjek \#2 (HL)}

Subjek merupakan mahasiswa semester empat program studi Pendidikan Agama Islam (PAI) Fakultas Tarbiyah, IAIN Madura. Respon fisiologis akabibat stres akademik yang dirasakan subjek adalah sering sakit perut dan ingin buang air besar tiap kali mengingat materi yang belum dipahami, pernah juga sangat lelah namun sulit untuk tidur. Sedangkan respon psikologisnya tidak mempunyai motivasi untuk membuka handphone (HP). Subjek mengaku pernah sengaja mematikan handphone (HP) untuk menghindari perkuliahan online yang sedang berlangsung, bahkan yang lebih ekstrim subjek sampai berpura-pura handphone (HP) nya rusak kepada salah satu dosen pengampu matakuliah. 
Subjek belum pernah mendengar tentang terapi mewarnai. Subjek beranggapan bahwa aktivitas mewarnai adalah aktivitas yang hanya dilakukan oleh anak kecil, bagaimana mungkin mahasiswa dan orang dewasa masih melakukannya dan bahkan bisa dijadikan sebagai metode untuk mengurangi stres akademik yang ia rasakan.

Ketika mencoba mewarnai gambar sederhana, subjek merasa kegiatan tersebut lucu dan tidak terlalu serius untuk mewarnai sampai selesai. Namun, ketika subjek sudah berhasil mewarnai sebuah gambar sederhana, subjek merasa lega dan ingin mengambar sekali lagi. Dengan tetap menggunakan gambar sederhana namun berbeda pola gambar, subjek mulai mewarnai kembali dengan penuh antusias dan menyelesaikan aktivitas mewarnainya dengan bagus. Subjek yang awalnya menganggap aktivitas mewarnai hanyalah aktivitas untuk anak kecil, kali ini ia mengaku bahwa ternyata mahasiswa dan orang dewasa juga butuh untuk melakukan aktifitas mewarnai. Kesulitan yang subjek alami saat mewarnai yaitu belum bisa memadukan berbagai macam warna pada satu gambar.

Subjek merasa senang saat melihat warna-warni yang ia coretkan pada pola gambar, apalagi ketika subjek berhasil mewarnai sebuah pola dengan baik. Subjek tidak hentihentinya tersenyum melihat kertas hasil karya mewarnainya. Perasaan yang subjek rasakan ketika mewarnai adalah bahagia, tenang dan kembali ceria. Perubahan tingkat stres akademik dapat dirasakan langsung oleh subjek. Setelah mewarnai, subjek tidak malas untuk membuka handphone dan mengikuti perkulihan online dengan semangat. Subjek juga tidak malu untuk mengungkapkan pendapat di grup whatsapp kelas dan berani bertanya mengenai materi apa yang belum dipahami kepada dosen pengampu matakuliah.

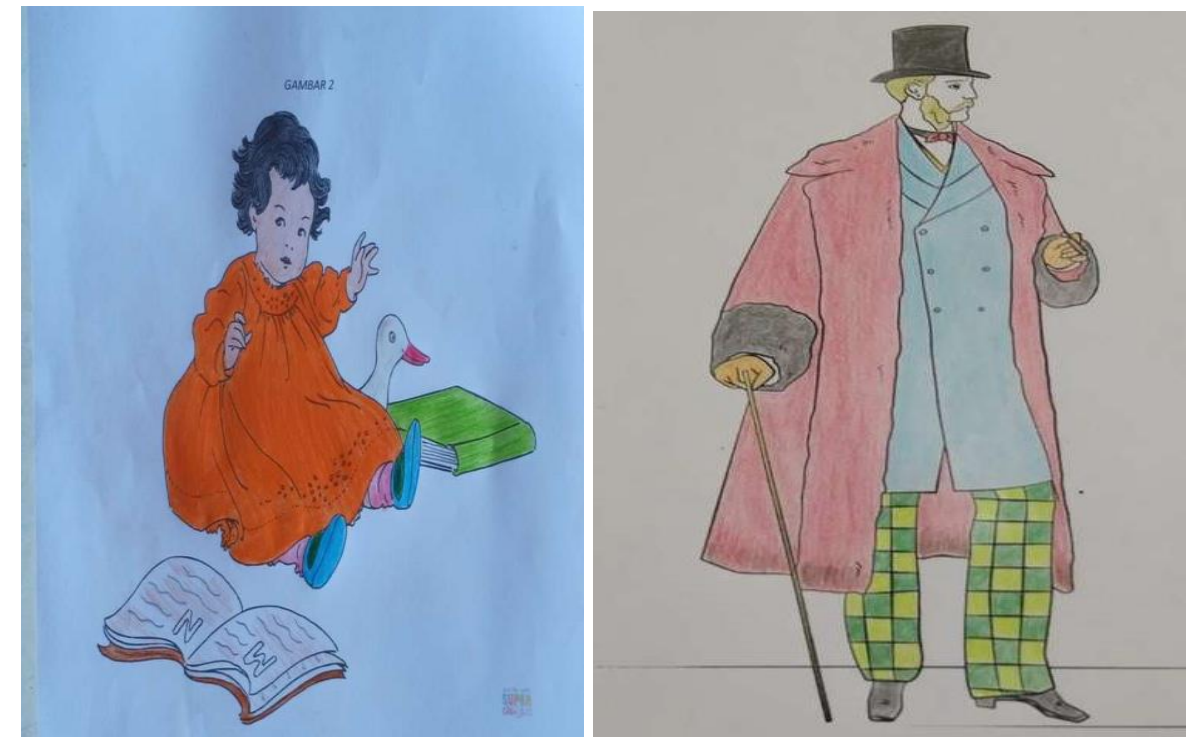

Gambar 2. Hasil mewarnai subjek 2 


\section{Subjek \#3 (RE)}

Subjek merupakan mahasiswa semester dua program studi Hukum Ekonomi Syari'ah (HES) Fakultas Syari'ah, IAIN Madura. Sebagai seseorang yang baru lulus dari Sekolah Mengah Atas (SMA) dan belum lama menyandang status sebagai mahasiswa, kuliah online adalah sistem perkulihan yang sangat baru dan penuh tantangan bagi subjek. Selain harus beradaptasi dengan peralihan status dari siswa menjadi mahasiwa, subjek juga diharuskan untuk menerima dan beradaptasi dengan sistem perkulihan yang semula tatap muka menjadi perkulihan online. Dua perubahan yang berbarengan tersebut mengakibatkan subjek mengalami stres akademik. Respon fisiologis yang subjek rasakan diantaranya: susah makan meski belum makan seharian, sering pusing, dan menjadi cepat lelah. Sedangkan respon psikologis yang subjek rasakan yaitu: bingung harus bertanya pada siapa ketika ada materi dan tugas yang belum dipahami, mengingat semua teman sekelas dan seangkatannya merupkan mahasiswa baru juga. Takut jika ketinggalan informasi dari dosen dan informasi lain terkait perkulihan online serta merasa bersalah jika telat mengikuti perkuliahan online.

Terapi mewarnai adalah hal yang baru bagi subjek. Subjek beranggapan bahwa terapi adalah kegiatan yang serius dan selalu berkaitan dengan peralatan-peralatan mahal. Subjek juga berpendapat bahwa kegiatan mewarnai tidak akan bisa dijadikan solusi untuk menurunkan stres akademik yang dialaminya. Ketika ditawari untuk melakukan aktivitas mewarnai, subjek menolak untuk melakukannya. Dengan alasan, tidak bisa mewarnai dan tidak punya bakat untuk mewarnai gambar. Namun, setalah mendapatkan penjelasan dan manfaat dari terapi mewarnai, subjek bersedia untuk melakukan aktivitas mewarnai.

Saat awal melakukan aktivitas mewarnai, subjek merasa kesulitan. Pertama, subjek kesulitan untuk memegang krayon karena sudah lama tidak memegangnya. Kedua, subjek kesulitan untuk mengaplikasikan krayon pada kertas karena terlalu kuat memegang krayon hingga mematahkan krayon yang dipegang. Namun, lama kelamaan subjek mulai menikmati aktivitas mewarnai yang dilakukan. Saat pertama kali berhasil mewarnai satu pola gambar, subjek tersenyum dan tersipu malu melihat gambar yang sudah ia warnai. Tidak sampai disitu, subjek ingin melakukan aktivitas mewarnai sekali lagi dan mencoba untuk lebih baik lagi dalam mewarnai gambar. Subjek menyadari bahwa mewarnai yang awalnya ia anggap sebagai kegiatan biasa, bisa membuat subjek senang dan bahagia melakukannya.

Aktivitas mewarnai memang bukanlah pengalaman baru, karena saat taman kanakkanak subjek sudah pernah melakukannya. Namun, ketika ia sudah menjadi mahasiswa, ia mengulangi kembali aktivitas tersebut. Awalnya memang subjek kesulitan, namun lama 
kelamaan subjek mulai menikmati dan senang melakukannya. Perasaan bahagia subjek rasakan ketika melihat warna-warni yang berpadu membentuk lapisan warna yang indah. Stres akademik yang dirasakan mulai berkurang. Subjek mencoba untuk menanyakan langsung pada dosen pengampu matakuliah mengenai materi yang belum ia pahami. Subjek juga semangat untuk mencari tahu informasi-informasi terkait perkuliahan melalui akun youtube fakultas, website kampus dan menghubungi pihak administrasi maupun pihak akademik fakultas.

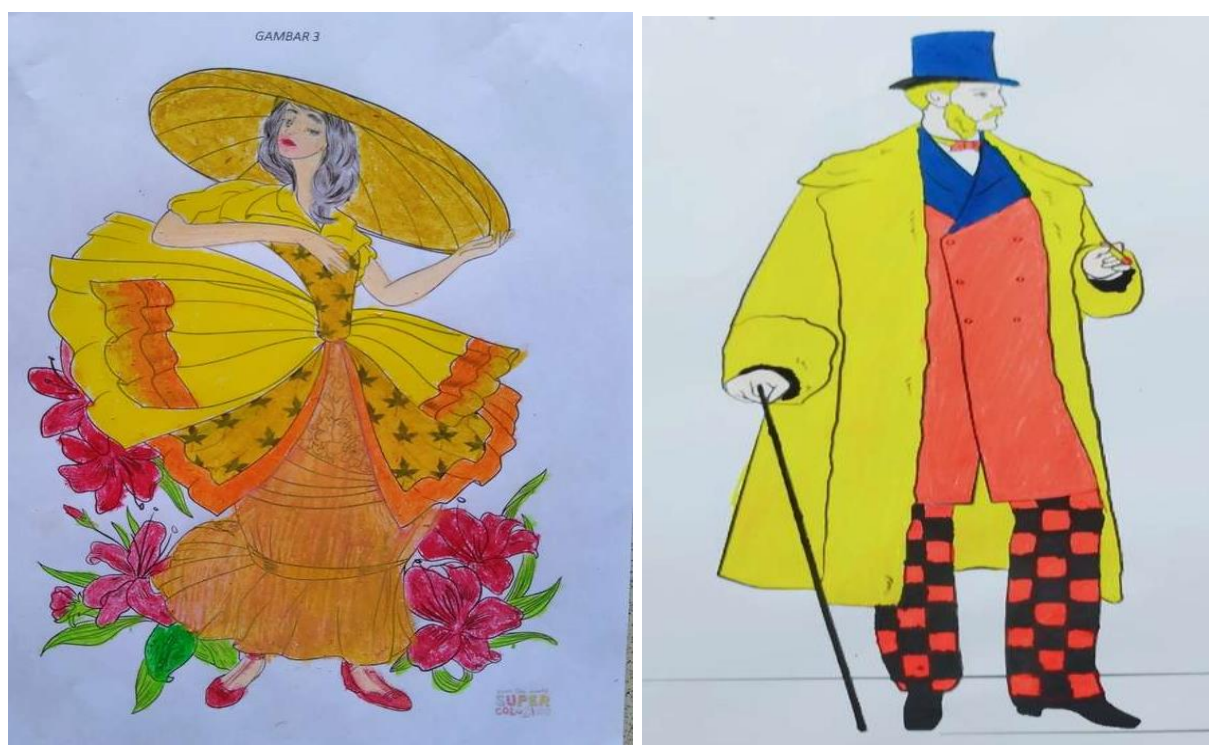

Gambar 3. Hasil mewarnai subjek 3

\section{Subjek \#4 (SA)}

Subjek merupakan mahasiswa semester enam program studi Perbankan Syari'ah (PS) Fakultas Ekonomi dan Bisinis Islam, IAIN Madura. Kuliah online awalnya membuat subjek senang karena tidak perlu repot untuk bangun pagi dan mempersiapkan perlengkapan untuk berangkat ke kampus. Subjek hanya perlu membuka handphone atau laptop saja meskipun belum sempat untuk mandi dan ganti baju. Namun ketika lebih dari satu tahun sistem kuliah online ia jalani, subjek merasa bosan dan kesepian setiap hari di rumah sendirian. Subjek merupakan anak tunggal, ayah subjek bekerja sebagai pengantar barang, begitu juga dengan ibu subjek yang bekerja sebagai karyawan pabrik rokok yang tidak bisa work from home (WHF) selama masa pandemi. Kondisi kesepian ini berdampak pada psikologisnya, subjek menjadi lebih pendiam dari biasanya, sering tidak mengerjakan tugas yang diberikan dosen, dan merasa kecewa pada orang tua yang tidak bisa mendampingi ataupun sekedar menyiapkan makanan saat perkulihan online berlangsung.

Subjek tidak pernah mendengar tentang terapi mewarnai. Subjek hanya mengetahui bahwa mewarnai adalah kegiatan anak taman kanak-kanak (TK). Meskipin subjek tidak 
mengetahui tentang terapi mewarnai, namun subjek sangat penasaran dan ingin mencoba mewarnai. Kegiatan berusur seni merupakan aktivitas yang subjek suka. Oleh karena itu, subjek sangat antusias untuk melakukan aktivitas mewarnai.

Saat pertama kali mencoba untuk mewarnai pola gambar yang sederhana, subjek merasa canggung dan kurang percaya diri. Subjek takut hasil akhir yang didapat tidak sesuai rencana karena sudah lama tidak melakukan kegiatan mewarnai. Namun, ketika selesai mewarnai pola subjek tersenyum bangga karena sudah berhasil mewarnai dengan baik. Melihat warna-warni yang ia hasilkan membuat pikirannya tenang dan perasaan menjadi damai. Subjek teringat masa kecil bersama orang tua, saat ibu dan ayah mengantarkan subjek mengikuti lomba mewarnai antar TK se-kecamatan. Memori indah bersama orang tua kembali hadir membuat subjek menyadari bahwa oarng tua subjek sangat menyayanginya. Subjek mulai menyadari bahwa apa yang orang tua nya kerjakan hari ini adalah demi masa depannya.

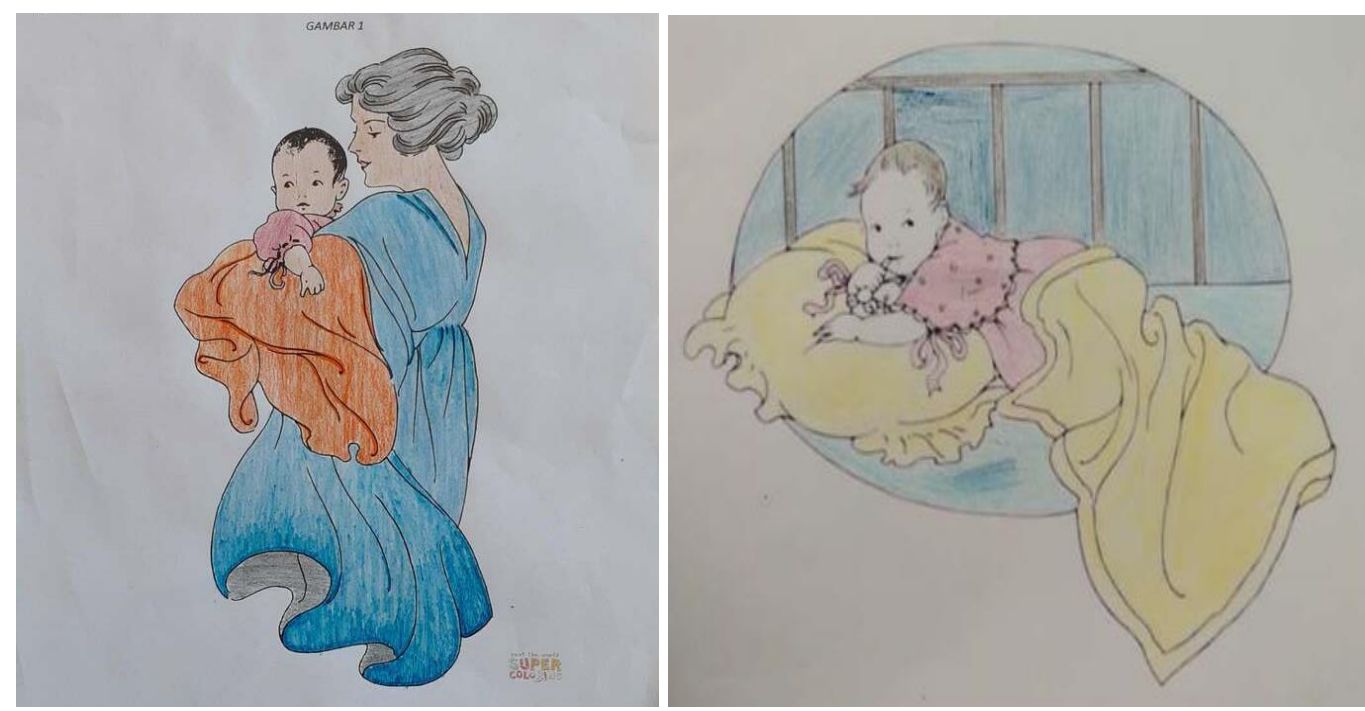

\section{Gambar 4. Hasil mewarnai subjek 4}

\section{Subjek \#5 (AE)}

Subjek kelima merupakan mahasiswa semester dua program studi Komunikasi dan Penyiaran Islam (KPI) Fakultas Ushuluddin dan Dakwah, IAIN Madura. Sitem perkuliahan online baru pertama kali subjek rasakan, mengingat subjek baru lulus dari Sekolah Menengah Atas (SMA). Dua perubahan yang berbarengan sekaligus membuat subjek mengalami stres akademik. Respon fisiologis yang subjek rasakan diantaranya: sering pusing, sulit makan, dan sering mengalami demam. Sedangkan respon psikologis yang subjek rasakan yaitu: bingung harus bertanya pada siapa ketika ada materi dan tugas yang belum dipahami, mengingat semua teman sekelas dan seangkatannya merupkan mahasiswa baru juga. Takut jika 
ketinggalan informasi dari dosen dan informasi lain terkait perkulihan online serta merasa bersalah jika telat mengikuti perkuliahan online.

Subjek baru mengetahui jika aktivitas mewarnai bisa dijadikan terapi. Selama ini subjek beranggapan bahwa mewarnai adalah aktivitas santai dan ringan yang hanya pantas dilakukan oleh anak kecil. Sangat jarang orang dewasa mewarnai, sekalipun ada mungkin orang dewasa tersebut berprofesi sebagai pelukis atau seniman. Subjek juga merasa malu untuk melakukan aktivitas mewarnai, dikarenkan takut dianggap seperti anak kecil. Namun, setalah mendapatkan penjelasan dan manfaat dari terapi mewarnai, subjek bersedia untuk melakukan aktivitas mewarnai.

Saat pertama kali mewarnai subjek masih merasa canggung dan malu untuk memulai. Namun ketika satu warna sudah mulai di goreskan pada pola gambar, semangat subjek perlahan-lahan bangkit dan tidak sabar ingin segera menyelesaikan aktivitas mewarnainya. Saat subjek berhasil mewarnai satu pola gambar, subjek merasa senang dan bangga. Ternyata dirinya masih bisa mewarnai dengan baik. Perpaduan warna yang dihasilkan cukup bagus dan rapi. Subjek merasa bersemangat untuk memulai mewarnai kembali. Kesulitan yang subjek rasakan selama proses mewarnai hanya dirasakan saat awal mewarnai saja, subjek masih terlihat tegang dan kaku saat memegang pensil warna.

Pengalaman saat mewarnai membuat subjek bahagia dan merasa senang. Menurut subjek warna-warni yang dipadukan terlihat indah dan membuat hati damai. Stres akademik yang miliki subjek perlahan berkurang. Saat melihat hasil mewarnai miliknya, semangat untuk menanyakan langsung pada dosen pengampu matakuliah mengenai materi yang belum ia pahami tiba-tiba muncul. Subjek juga berinisiatif untuk mencari tahu informasi-informasi terkait perkuliahan melalui akun youtube fakultas, website kampus dan menghubungi pihak administrasi maupun pihak akademik fakultas. 


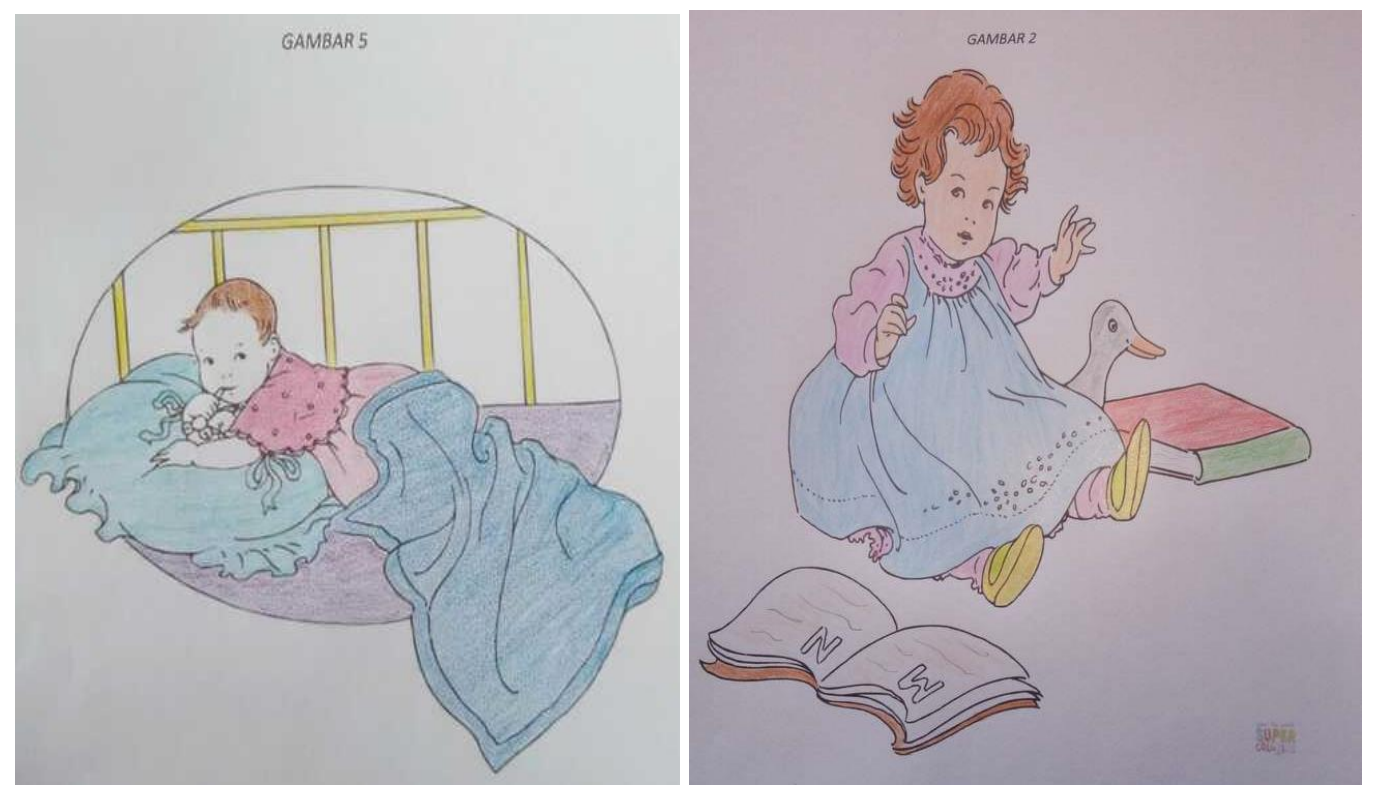

Gambar 5. Hasil mewarnai subjek 5

\section{PEMBAHASAN}

Perubahan tingkat stres akademik pada Subjek 1 (MB) adalah subjek mempunyai semangat untuk membuka kembali materi-materi yang telah diberikan oleh dosen dan mulai mengerjakan tugas yang diberikan dengan perasaan senang dan tenang. Subjek 2 (HL) tidak malas untuk membuka handphone dan mengikuti perkulihan online dengan semangat. Subjek juga tidak malu untuk mengungkapkan pendapat di grup whatsapp kelas dan berani bertanya mengenai materi apa yang belum dipahami kepada dosen pengampu matakuliah. Subjek 3 (RE) mencoba untuk menanyakan langsung pada dosen pengampu matakuliah mengenai materi yang belum ia pahami. Subjek juga semangat untuk mencari tahu informasi-informasi terkait perkuliahan melalui akun youtube fakultas, website kampus dan menghubungi pihak administrasi maupun pihak akademik fakultas. Subjek 4 (SA) mulai menyadari bahwa apa yang orang tua nya kerjakan hari ini adalah demi masa depannya. Subjek 5 (AE) semangat untuk menanyakan langsung pada dosen pengampu matakuliah mengenai materi yang belum ia pahami.

Perubahan yang dialami oleh kelima subjek sesuai dengan pernyataan Malchiodi (2001) terapi seni pada tema tertentu yang berkaitan dengan peristiwa atau kondisi tertentu dapat mempengaruhi emosi dan pikiran individu. Penelitian ini membuktikan bahwa terapi seni mewarnai dapat menurunkan rasa gelisah dan kecemasan individu sebagaimana didukung oleh hasil penelitian sebelumnya yang telah dilakukan oleh Asnani (2020) menyatakan adanya manfaat setelah diberikannya intervensi terapi seni mewarnai. Adapun perubahan yang terjadi setelah diberikannya intervensi ini adalah secara fisik partisipan 
merasa lebih rileks, secara kognitif lebih inspiratif, secara emosi sudah lebih semangat, antusias, sudah dapat mengelola perasaan dan emosi. Secara perilaku sudah mulai tertawa dan lebih rajin.

Banyak faktor pendukung dan juga penghambat bagi ke lima subjek saat melakukan aktivitas mewarnai. Faktor pendukungnya adalah 1) Keinginan atau tekad yang kuat untuk menghilangkan stres akademik yang dialami; 2) Lokasi atau tempat yang dipilih untuk melakukan aktivitas mewarnai adalah tempat yang bersih, asri dan tenang; dan 3) Melakukan aktivitas mewarnai sambil mendengarkan musik, bercerita dengan keluarga, sambil makan cemilan kesukaann dan minum minuman favorit, ada yang menyendiri di kamar disesuaikan dengan hobi dan kesukaannya masing-masing. Sedangkan faktor penghambatnya adalah 1) ke lima subjek sudah lama tidak mewarnai, mengakibatakan tangan dan jari masih kaku saat awal mewarnai; 2) ada rasa tidak percaya diri karena tidak punya bakat mewarnai; dan 3) belum terbiasa memegang crayon atau pensil warna.

Berbagai penelitian membuktikan bahwa terapi seni melalui gambar dapat meningkatkan kesadaran diri, menyelesaikan konflik emosional dan mampu menyelesaikan permasalahan (The American Art Therapy Association, 2003). Warna-warna yang subjek lihat dan coretkan membangkitkan semangat dan membuat perasanan tenang dan damai. Warna yang ada di sekitar individu dapat menurunkan kecemasan. Proses penurunan kecemasan dengan menggunakan warna dapat menghasilan rasa tenang dan nyaman yang disebabkan oleh hormon serotonin didalam otak (Radeljak dkk, 2008). Pada awalnya kelima subjek beranggapan bahwa terapi mewarnai adalah aktivitas yang hanya lazim dilakukan anak kecil, subjek menyatakan bahwa sangat lucu jika orang dewasa masih melakukan hal tersebut kecuali orang dewasa yang memang berprofesi sebagai pelukis atau seniman. Namun pernyataan tersebut tidak berlaku lagi saat kelima subjek sudah berhasil mewarnai dan merasakan efek dari aktivitas mewarnai.

\section{SIMPULAN}

Berdasarkan hasil penelitian diketahui bahwa kelima subjek mengalami penurunan tingkat stres akademik setelah melaksanakan aktivitas terapi mewarnai. Tampak pada semangat dan usaha kelima subjek untuk kembali aktif mengikuti perkuliahan online, semangat mengerjakan tugas yang diberikan dosen dan semangat untuk bertanya serta mencari tahu secara mendiri mengenai informasi seputar materi maupun informasi perkulihan yang belum dipahami. 
Terapi mewarnai merupakan salah satu terapi yang menggunakan gambar dan warna sebagai media untuk melakukan identifikasi dan eksplorasi perasaan. Melalui gambar dan warna, individu bisa mendeskripsikan serta menilai diri sendiri. Sehingga, aktivitas seni mewarnai mampu menurunkan tingkat stres akademik mahasiswa akibat kuliah online. Proses terapi dapat menumbuhkan keyakinan atas kemampuan diri dan memberi bekal kekuatan pada diri sehingga memungkinkan individu menghadapi segala permasalahan dan melaksanakan tugas dengan baik.

Pada penelitian selanjutnya kiranya dapat diujicobakan penelitian eksperimen terhadap mahasiswa dengan jumlah partisipan yang lebih banyak. Diharapkan pelaksanaannya dilakukan secara group therapy atau kelompok agar dapat diketahui perbedaan keefektivan terapi mewarnai jika diberikan secara individu dengan secara berkelompok.

\section{DAFTAR RUJUKAN}

Amiruddin, H. (2020). Cari Sinyal Internet untuk Kuliah Online, Mahasiswa Jatuh dari Menara

Aryani, F. (2016). Stres belajar; Suatu pendekatan dan intervensi konseling . Palu: Edukasi Mitra

Grafika.

Asnani, S. (2020). Efektivitas Terapi Seni Mewarnai Untuk Menurunkan Depresi Pada Remaja Putri;

Single One Shot Case Study. Journal of Psychological Perspective | Vol 2 (2), December 2020. https://ukinstitute.org/journals/jopp

Fatmawati, A. (2015). Kajian Literatur : Efektifitas Art Therapy dalam Meningkatkan Kualitas Hidup

dan Kesehatan Psikologis Pasien Penyakit Gagal Ginjal Kronik yang Menjalani Hemodialisis. Medica Majapahit, 9(1), 1-32.

Gunadha, R., \& Rahmayunita, H. (2020). Kuliah Online saat Corona Picu Ketimpangan Akses Bagi

Heksan, L.N. (2010). Peran Art Therapy Dalam Mengurangi Kecemasan Pada Middle Childhood

yang Mengalami Perceraian Orangtua. (Unpublished Thesis). Fakultas Psikologi Universitas Tarumanagara, Jakarta.

Malchiodi, C.A. (2001). Using Drawing as Intervention with Traumatized Children. Trauma and Loss: Research and Intervention, 1 (1)

Malchiodi, C.A. (2013). What is Art Therapy?. Diunduh dari

http://www.psychologytoday.com/blog/the-healingarts/201304/defining-art-therapy-in-the-

21st-century

Mappi, H. (2020). Mahasiswi Unismuh Makassar Meninggal Saat Cari Internet untuk Kuliah Online.

Panchanov, R. (2020). Keluh Kesah Mahasiswa Kuliah Online, dari Internet Lelet hingga Gagal Paham. Retrieved March 28, 2020, from 
https://radarlampung.co.id/2020/03/28/keluh-kesah-mahasiswa-kuliahonline-dariinternet-lelet-hingga-gagal-paham/

Radeljack, S., Zarkovic-Palijan, T., Kovacevic, D., \& Kovac, M. (2008). Chromotherapy in the

regulation of neurohormonal balance in human brain - complementary application in modern psychiatric treatment. Collegium Antropologie. (32). 185-188

Satria, A. (2020). Wabah Corona dan Adaptasi Perguruan Tinggi. Retrieved April 15, 2020, from

https://news.detik.com/kolom/d-4977685/wabah-corona-dan-adaptasi-perguruan-tinggi

Shadi, M., Peyman, N., Taghipour, A., \& Tehrani, H. (2018). Predictors of the academic stres and

its determinants among students based on the theory of planned behavior. Fundamentals of Mental Health , 20 (1), 87-98.

The American Art Therapy Association. (2003). Frequently asked questions about art therapy. Dikutip

dari http://www.arttherapy.org/aboutarttherapy/about.htm. pada May, 25, 2020.

Universitas Indonesia (2020). Pengertian Kuliah Daring. Diakses pada 12 Mei 2021, darihttps://www.ui.ac.id/sumber-belajar-daring.html

Wahyuni, N. E. (2017). Mengelola Stres Dengan Pendekatan Cognitive Behavior Modification. (Studi

Eksperimen Pada Mahasiswa Baru Pendidikan Agama Islam(Pai) FakultasIlmu Tarbiyah\&Keguruan Uin MalikiMalang).88 (1). 99117.

Retrieved April 8, 2020, from https://news.detik.com/berita/d-4970244/mahasiswi-unismuhmakassarmeninggal-saat-cari-internet-untuk-kuliah-online

Mahasiswa Miskin. Retrieved April 16, 2020, from https://www.suara.com/news/2020/04/16/130712/kuliah-online-saat-corona-picuketimpangan-aksesbagi-mahasiswa-miskin

Masjid. $\quad$ Retrieved May $\quad$ 9, 2020, from https://news.okezone.com/read/2020/05/09/609/2211324/cari-sinyalinternet-untukkuliah-online-mahasiswa-jatuh-dari-menara-masjid 